\title{
PROJECT IMAF - RESEARCH ON MEASUREMENT OF AIRSPEED OF UNCONVENTIONAL FLYING VEHICLES
}

\author{
Peter GASPAROVIC*, Ladislav FOZO, Michal HOVANEC, Karol SEMRAD \\ Technical University of Kosice, Faculty of Aeronautics, Rampová 7, Košice, Slovakia \\ *Corresponding author. E-mail: peter.gasparovic@tuke.sk
}

\begin{abstract}
Article presents the project of "Innovative measurement of airspeed of unconventional flying vehicles", its background, contents and planned activities.
\end{abstract}

Keywords: airspeed; measurement; unconventional flying vehicles

\section{INTRODUCTION}

On May 14th of 2021 the Slovak research and development agency (Slovak abbreviation APVV) decided to provide financial resources for our project with the name of "Innovative measurement of airspeed of unconventional flying vehicles" (acronym IMAF, code APVV-20-0546). Presented are background and topic of this project, planned activities and research infrastructure.

\section{BACKGROUND OF THE PROJECT}

Sensing the static pressure of the free stream is the basis for measuring the speed of flying devices. Reliable measurement of flight speed under all flight conditions is a basic prerequisite for safe flight and is therefore part of the certification criteria for aircraft. At present, several projects of development of unconventional flying vehicles have appeared, e.g. autogyros (also called gyrocopters) and flying cars for which it is not appropriate to use the traditional method of measuring airspeed. There are several autogyro projects in the world, but the most interesting designs include the Nisus autogyro by the Slovak developer Jokertrike s.r.o. Slovakia is one of the world's pioneers in the development of flying cars, because the project of the Slovak company AeroMobil s.r.o. It already exists in the fifth generation and has a great chance of obtaining certification and reaching series production. In addition, there is a second team in Slovakia, developing a similar type of flying car, led by Ing. Stefan Klein.

The traditional method of measuring aircraft airspeed is based on the measurement of the impact air pressure and conversion of the impact pressure to airspeed data [1] [2]. The impact pressure is the difference between the Pitot pressure and the static pressure, which are the result of aerodynamic phenomena in the flowing air. Airspeed means the relative speed between the aircraft and a homogeneous air environment at an infinite distance from the aircraft, where the disturbances caused by the presence of the aircraft no longer occur. This environment is referred to as "free stream" [1].

According to the fluid flow theory, the relationship between the value of the impact pressure and the relative velocity of the free flow is unambiguous in both directions, i.e. one value of the impact pressure can be assigned exactly to one velocity value, and vice versa. The conversion between the two values is done mechanically, in an air speedometer, which is essentially a relative pressure gauge. Pitot pressure and static pressure enter it, and the instrument shows speed directly. This type of device is very simple, does not require a power source, and due to its reliability, its use is widespread.

The different system is of a necessity on stealth aircraft, where traditional total pressure probes cause intense reflection of radar waves. The B-2 bombers of the stealth category, in the USA, use a system of surface pressures [3]. A similar system was previously used on the X-15 [4] hypersonic 
aircraft and later on the X-33 [5] space shuttle, where aerodynamic heating was damaging traditional pressure probes protruding from the surface. The surface system has also been used on small unmanned aerial vehicles, where miniature dimensions and the resulting low Reynolds number make it impossible to measure accurately using a traditional total pressure probe.

The traditional method of measuring aircraft airspeed requires accurate measurement of Pitot pressure and static pressure of free stream. The Pitot pressure is measured by a Pitot tube that protrudes from the surface in front of the aircraft. The static pressure is measured by a static port orifice, which is located at a suitable place on the surface of the aircraft, or which is located on a pitotstatic probe, which is protruded at a greater distance in front of the aircraft or in front of the wing. The measurement error can be reduced by increasing the length of the probe and choosing a location on the surface of the aircraft. The principle of measurement is described in the NASA reference publication [3].

Both pressures are sensitive to changes in flow direction. The Pitot pressure error is measurable only when the yaw angle is above 10 degrees (the error is then more than 1\%) [6]. The static pressure error is measurable even when deviating above 1 degree, and it is the main source of airspeed measurement error for all aircraft that use this method of measurement. It is not possible to use a long pitot-static probe in the mentioned projects of unconventional flying vehicles. For example, with a flying car, a probe protruding from the front could often be damaged, or people moving near it could be injured. In the case of a autogyro, the use of a long probe is not the solution, because the yaw angle usually reaches a value in tens of degrees.

One of the problems with unconventional flying vehicles (autogyros, flying cars, etc.) is reliable speed measurement over the entire range of flight conditions (e.g. for autogyros even at large yaw angles), because the correct speed data is one of the basic conditions for safe flight and, and is verified during the certification of flying vehicles. In order to achieve this state, new possibilities for measuring airspeed need to be developed. The research is focused on the study and analysis of the current state of static probe types; design and development of better types of static probes; selecting a suitable location for the pressure probes, which is related to the effect of the location on the variability of the local flow direction and on the positional error of the static pressure; and analysis and design of the possibility of another method of obtaining impact and static pressure, e.g. using a total energy pressure probe; and last but not least to verify, verify the implemented solution design, laboratory tested, for selected unconventional flying equipment in full scale and in real conditions.

The topicality of the proposed solution procedures is proved by the accident of the prototype AeroMobil on 2015-05-08, where the commission of inquiry recommended to change the method of static pressure probing [18].

\section{PROJECT GOALS}

The main goal is to improve the flight safety of unconventional flying transport equipment and to support the competitiveness of Slovak industry. It will be achieved by developing an innovative measurement of airspeed using air pressures on unconventional flying vehicles at large yaw angles and its implementation on a selected real device (Nisus autogyro from the manufacturer JOKERTRIKE or flying car, etc.) in real flight conditions. To achieve the main goal, it is necessary to meet the following sub-goals during the project:

- Preparation for the modernization of the wind tunnel laboratory at the Faculty of Aviation of the Technical University in Košice. This zero sub-objective involves the modification and overhaul of wind tunnels so that experiments can be performed in them with the required accuracy and in a reasonable time, i.e. as automatically as possible. The high-speed tunnel will have to undergo a overhaul of its propulsion. The low-speed tunnel will have to be supplemented with parts to improve the quality of the flow (rectifying honeycomb and homogenisation screens). The electronic velocity measurement system will allow direct measurement of turbulence (by the hot-wire method). The new electronic pressure measuring system will make it possible to measure differential pressures with an accuracy of $0.05 \%$ of the measured range and absolute pressures with an accuracy of $0.5 \%$ of the 
measured range. The apparatus for measuring absolute pressure will be transferable so that it can also be used for measurements during flight tests. The output will be a modernized laboratory.

- The first sub-objective, the output of which will be data, is to gain knowledge about existing methods of measuring static pressure and, based on such a knowledge base, to design at least one new static pressure probe. The means will be mathematical modeling, numerical calculation and experiment. The output will be data and design of new types of static probes.

- Examining the influence of the position on the surface of the flying device on the variability of the direction of the local flow and the deviation from the static pressure of the free flow will be the second sub-objective. Variability is the sensitivity to yaw angle of the incoming air stream. Due to the required volume of data, the means will be mainly a numerical calculation, supplemented by an experiment, to confirm the prediction at selected points.

- The third sub-objective will be the analysis of a new way of the measurement of the pressures and airspeeds, using a total energy probe. The tool will be a numerical calculation and an experiment in a wind tunnel.

- The last goal is to verify one or more solutions in flight with the subsequent implementation of the best solution on a real flying device - on a Jokertrike autogyro. The chosen solution will be verified by further flight tests.

The reality of achieving the project objectives is supported by previous theoretical and practical experience captured in the publications of the research team in the project area, and long-term and systematic work on the topic, the first result of which is a proposal for a new method of measuring air speed by probing the air pressure with a total energy probe (see application for a utility model [17]). Many years of rich experience and positive responses, final reports of projects solved so far (especially the European project FP7 - Framework Program) of the responsible researcher, Dr. Fozo, suggest a high probability of fulfilling the project objectives.

Another guarantee is the existence of an aerodynamic laboratory consisting mainly of two larger wind tunnels - a low-speed wind tunnel $100 \times 50 \mathrm{~cm}$ and a high-speed wind tunnel $30 \times 60 \mathrm{~mm}$. The possibilities of this infrastructure, which is unique in Slovakia, will be extended by a more accurate and automated pressure measurement after approval of the proposed project.

The existence of the HPC workplace for high-performance computing, which was built from the funds of the all-Slovak SIVVP project, is another guarantee of achieving the project's goals. The hardware and software will be used in numerical simulations.

\section{PROPOSED SOLUTIONS}

There are proposals of other static pressure probes (e.g. [7]) which, due to their suitable shape, have a reduced sensitivity to the yaw angle, but their properties have not yet been published. Preliminary was done a measurement of properties of the Broezel probe [8] [9] [10], which is commercially available and is used only on gliders, for accurate measurement of the rate of climb, although it is used on the basis of unpublished measurements of the inventor of this type of probe. The required measurement accuracy in the assessment of pressure probes exceeds the criteria for wind tunnel measurements or in numerical flow simulation [11] [12]. The assessment of probes requires not only pressure gauges with higher sensitivity [13], but also a wind tunnel with detailed knowledge of the current field quality [14] [15]. Numerical simulation requires careful mesh preparation, or the use of a panel calculation method [16], which does not require a volume mesh and the accuracy of its results is not affected to such an extent by numerical diffusion.

Another proposed solution is to develop system of surface pressures. To design such system we need digital geometry of the flying device, which will be obtained by optical scanning using laser 3D scanners. Prediction of the flow and pressure field of probes and flying equipment will be made by the method of numerical simulations using ANSYS software on the hardware of the HPC TUKE computer. 


\section{Acknowledgement}

This work was supported by the Slovak Research and Development Agency under the Contract no. APVV-20-0546.

\section{References}

[1] J. Hošek, Aerodynamika vysokých rychlostí. Praha: Naše vojsko, (1949)

[2] W. S. Aiken, "Standard nomenclature for airspeeds with tables and charts for use in calculation of airspeed," NACA-TR-837, (1946)

[3] 2008 Andersen Air Force Base B-2 accident, Accident Investigation Board, "Summary of Facts" http://www.glennpew.com/Special/B2Facts.pdf

[4] J.P. Carry, E.R. Keener, „Flight evaluation of the X-15 ball-nose flow-direction sensor as an airdata system, " Správa NASA-TN-D-2923 (1965)

[5] S.A. Whitmore, B.R. Cobleigh, E.A. Haering, „Design and Calibration of the X-33 Flush Airdata Sensing (FADS) System“, Správa NASA/TM-98-206540 (1998)

[6] W. Gracey, Measurement of Aircraft Speed and Altitude, Správa NASA-RP-1046, (1980)

[7] A. M. O. Smith, A. B. Bauer, J. of Fluid Mech., 44, 513-528 (1970)

[8] P. Gašparovič, "Flat static probe insensitive to yaw," in: 29th symposium on anemometry: Proceedings: 2. - 3.6.2015: Holany-Litice, Praha, 2015, pp. 18-20.

[9] P. Gašparovič, M. Cúttová, "Properties of Flat Broezel Static Probe used for Accurate Measurement of Flight Airspeed of the Aircraft," in: Transport Means 2015 : Proceedings of the 19th international scientific conference: October 22-23, 2015, Kaunas University of Technology, Lithuania, 2015, pp. 425-428.

[10] P. Gašparovič, K. Semrád, M. Cúttová, "Properties of Broezel static probe," in: Proceedings of the International conference Experimental Fluid Mechanics 2015 : November 17.-20., 2015 : Prague, Czech Republic, Praha, 2015, pp. 194-197. doi:10.1051/epjconf/201611402026 [Online]

[11] P. Gašparovič, "Convergence of inviscid axial-symmetric flow past sphere," in: TechSoft Engineering ANSYS 2015: Setkání uživatelů a konference: Sborník: 27. - 29.5.2015: Hotel Zámek Valeč, Praha, 2015, pp. 1-6.

[12] P. Gašparovič, P. Szabó, "Comparison of numeric and exact solution of pressure far flowfield," in: New Trends in Aviation Development 2016 : Proceedings of the XII. International Scientific Conference : Kosice, September 8 - 9, 2016, 2016, pp. 1-6.

[13] P. Gašparovič, M. Cúttová, "Properties of silicone tubing micromanometer," in: Zborník príspevkov z vedeckej konferencie s medzinárodnou účast’ou: Senzorika a magnetometria 2013, 5. decembra 2013, Košice, Slovenská republika, Košice, 2013, pp. 19-25.

[14] P. Gašparovič, I. Ganobčík, T. Brestovič, M. Hovanec, L. Főző, "Improvement of wind tunnel flow with screens," in: New Trends in Aviation Development 2019 : 26.09.2019-27.09.2019 : Castle Karlova Koruna, Danvers (USA), 2019, pp. 64-67.

[15] P. Gasparovic, S. Fabry, L. Fozo, M. Hovanec, K. Semrad, "Measurement of turbulence in wind tunnel with screens," in: Acta Avionica, vol. 21, no. 2, pp. 1-7, 2019. doi:10.35116/aa.2019.0018

[16] J.L. Hess, „Panel Methods in Computational Fluid Dynamics,“ in: Annual Review of Fluid Mechanics, vol. 22: pp. 255-274, 1990. doi: 10.1146/annurev.fl.22.010190.001351

[17] P. Gasparovic, S. Fabry, Žiadost' o zápis úžitkového vzoru PUV 133-2019. https://wbr.indprop.gov.sk/WebRegistre/UzitkovyVzor/Detail/133-2019.

[18] Záverečná správa vyšetrovacej komisie SKS2015001- https://www.mindop.sk/ministerstvo1/doprava-3/letecky-a-namorny-vysetrovaci-utvar/zaverecne-spravy/rok-2015/2015-zaverecnespravy/sks2015001-08-05-2015-om-m929

Received 10, 2021, accepted 11, 2021

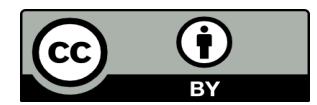

Article is licensed under a Creative Commons Attribution 4.0 International License 